
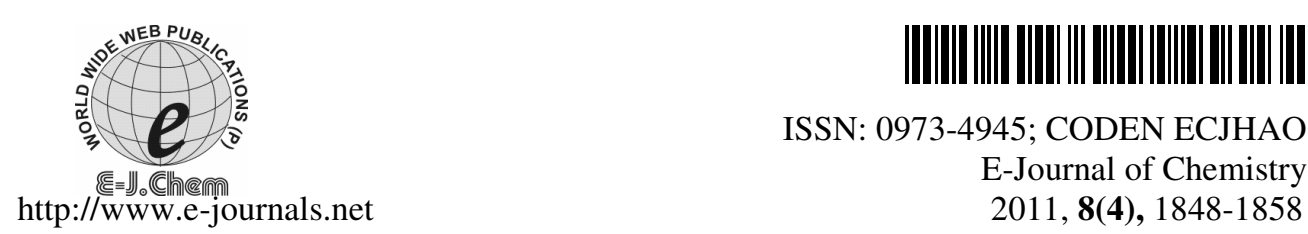

ISSN: 0973-4945; CODEN ECJHAO

E-Journal of Chemistry 2011, 8(4), 1848-1858

\title{
Spectral Characterization and Antibacterial Activities of Benzyloxybenzaldehydethiosemicarbazone, 3,4- Dihydroxybenzaldehydeisonicotinoylhydrazone and their Transitional Metal Complexes
}

\author{
LAKSHMI NARAYANA SUVARAPU ${ }^{\S *}$, A VARADA REDDY", \\ G. SATHEESH KUMAR and SUNG OK BAEK ${ }^{\S}$ \\ ${ }^{\S}$ School of Environmental Engineering, Yeungnam University \\ Gyeongsan-Si, Republic of Korea - 712749 \\ ${ }^{\#}$ Analytical Division, Department of Chemistry \\ S.V. University, Tirupati-517 501 India \\ Recombinant Gene Product (RGP), \\ International Centre for Genetic Engineering and Biotechnology (ICGEB), \\ New Delhi - 110067 \\ lakshminarayana_chem@rediffmail.com
}

Received 12 March 2011; Accepted 14 April 2011

\begin{abstract}
The synthesis and spectral characterization of benzyloxybenzaldehydethiosemicarbazone (BBTSC) and the study of antibacterial activity of ligands BBTSC, 3,4-dihydroxybenzaldehydeisoni-cotinoylhydrazone (3,4-DHBINH) and their transition metal complexes was studied. The composition of the metal complexes was also evaluated by using Job's method, molar-ratio method and Asmus' method. The antibacterial activities of BBTSC, 3,4-DHBINH and their complexes i.e., $\mathrm{Cu}(\mathrm{II})$-BBTSC, Pd(II)-BBTSC, Cr(VI)- 3,4-DHBINH, Ti(IV)- 3,4DHBINH and Pd(II)-3,4-DHBINH were studied against two gram positive bacteria and two gram negative bacteria. Antibacterial activities were evaluated by agar cup well method with the help of Luria Bertoni plates.
\end{abstract}

Keywords: BBTSC, 3,4-DHBINH, Antibacterial activity,Transitional metal complexes

\section{Introduction}

Thiosemicarbazones form a class of mixed hard-soft oxygen/nitrogen-sulphur chelating ligands that show a variety of coordination modes in metal complexes. The thiosemicarbazones can act as a monodentate ligand that binds to the metal ion through the sulphur atom ${ }^{1}$ or as a bidentate ligand that coordinates to the metal ion through the sulphur atom and one of the nitrogen atoms of the hydrazine moiety to form four or a five membered chelate rings ${ }^{2,3}$. 
The coordination capacity of thiosemicarbazones can be increased due to the presence of aldehydes or ketones containing additional functional group(s) in position(s) suitable for chelation ${ }^{4}$. Besides their interesting coordination chemistry, thiosemicarbazones have attracted considerable interest because of their potentially beneficial biological activities such as antiviral ${ }^{5}$, antitumour ${ }^{6}$, antimalarial ${ }^{7}$, antifungal ${ }^{8}$ and antibacterial ${ }^{9}$. The biological activity of thiosemicarbazones and metal-thiosemicarbazones has been receiving considerable attention recently ${ }^{10-12}$.

A good number of reports are available on the biological activity of transition metal complexes of thiosemicarbazones ${ }^{13-15}$. The mechanism of biological activity of thiosemicarbazones is due to their ability to inhibit the biosynthesis of DNA, possibly by blocking the enzyme ribonucleotide diphosphate reductase; binding to the nitrogen bases of DNA, hindering or blocking base replication; creation of lesions in DNA stands by oxidative rupture ${ }^{16}$. In some cases the activity is associated with a metal atom. Several palladium(II) and platinum(II) thiosemicarbazone complexes having potential antitumor activity have been recently reported ${ }^{17-20}$.

Collins et $a l^{21}$ have reported the correlation between structure and antibacterial activity in a series of 2-acetylpyridinethiosemicarbazone. In many cases, by coordination to different transition metal ions that can be found in biological systems, it is possible to obtain complexes that are more efficient drugs than the corresponding free ligands $^{22-24}$. Some important thiosemicarbazones with antibacterial activity reported earlier are discussed here under.

Kovala-Demertzi et $a l^{25}$ have reported the anti-tumor activity of 2-acetylpyridine- $4 \mathrm{~N}$ ethylthiosemicarbazone and its platinum(II) and palladium(II) complexes. Elena Bermejo et $a l^{26}$ have reported the biological activities of complexes of zinc(II), cadmium(II), mercury(II), palladium(II) and platinum(II) with 2-acetylpyridine- 4-methylthiosemi-carbazone and its metal complexes assayed in vitro for antifungal activity against the pathogens Aspergillus niger and Paecilomyces variotii. Among the above mentioned transition metal complexes only zinc(II) complex shows some activity at a concentration of $600 \mu \mathrm{g} \mathrm{mL}^{-1}$. The minimum inhibition zone for zinc(II) complex is found as $9.5 \mathrm{~mm}$.

Dimitra Kovala-Demertzi et $a l^{27}$ have reported the antibacterial and antifungal activities of nickel(II) and palladium(II) complexes of 2-acetyl-pyridinethiosemi-carbazone. Antibacterial activities are evaluated against gram positive bacteria Staphylococcus aureus and gram negative bacteria Escherichia coli. Antifungal activity is evaluated against candida albicans.

Sulekh Chandre et $a l^{28}$ have reported the antimicrobial activities of copper(II) and nickel(II) complexes with benzil bisthiosemicarbazone against the gram positive bacteria (Bacillus macerans) and gram negative bacteria (Pseudomonas striata). The authors reported that the metal chelates exhibit more inhibitory effects than the parent ligand.

\section{Antibactrial activity of hydrazones and their complexes}

Interest in the study of hydrazones has been growing because of their antimicrobial, antituberculosis and antitumor activities ${ }^{29-30}$. Hydrazones play an important role in inorganic chemistry, as they easily form stable complexes with most of the transition metal ions. The development of the field of bioinorganic chemistry has increased the interest in hydrazone complexes, since it has been recognized that many of these complexes may serve as models for biological important species ${ }^{31}$. Coordination compounds derived from aroylhydrazones have been reported to act as enzyme inhibitors and are useful due to their pharmacological applications $^{32-35}$. 
Hydrazones possessing an azometine $-\mathrm{NHN}=\mathrm{C} \underline{H}$-proton constitute an important class of compounds for new drug development. Therefore, many researchers have synthesized these compounds as target structures and evaluated their biological activities.

Hydrazones and their metal complexes are biologically very active compounds. For example Ragavendran et $a l^{36}$ have reported anticonvulsant activity of 4-aminobutyricacidhydrazone, Abdel-Aal et $a l^{37}$ have reported antiviral activity of $N$-arylaminoacetylhydrazones against Herper simplex virus- 1 and Hepatitis-A virus(HAV), Walcourt et al $l^{38}$ have reported antimalarial activity of 2-hydroxy-1-naphthaldehyde -isonicotinoylhydrazone and Savini et $a l^{39}$ have reported antitumor activity of 3- and 5-methylthiophene-2-carboxaldehyde $\alpha$ - $(N)$-heterocyclichydrazone derivatives. Recently critical reviews have been published by various authors on antibacterial activity of hydrazones ${ }^{40-42}$.

A thorough literary survey has revealed that a good number of thiosemicarbazone and hydrazone complexes are evaluated for antibacterial activity against various bacteria. But potentiality of these complexes is not fully utilized. Hence, the newly synthesized copper(II) and palladium(II) complexes of benzyloxybenzaldehydethiosemicarbazone (BBTSC) and vanadium(V), chromium(VI), titanium(IV) and palladium(II) complexes of 3,4-dihydroxybenzaldehydeisoni-cotinoylhydrazone(3,4-DHBINH) are tried to evaluate antibacterial activity.

\section{Experimental}

Klebsiella pneumoniae, Staphylococcus aureus, Escherichia coli and Pseudomonas aeruginosa were grown at $37{ }^{\circ} \mathrm{C}$ and maintained on LB plates (Luria-Bertani broth, with $2.0 \%$ agar) for $18-20 \mathrm{~h}$.

\section{Assay of antibacterial activity by Agar cup well method}

Preparation of overnight bacterial culture

The LB broth (Hi media) medium was inoculated with selected bacterial culture under sterile conditions and incubated at $37^{\circ} \mathrm{C}$ for $18-20 \mathrm{~h}$. This developed inoculum was used for further assay.

\section{Preparation of $L B$ plates}

The LB agar medium was prepared and poured in petri plates and allowed to solidification.

\section{Inoculation of bacterial culture on LB medium by spread plate method}

The overnight bacterial culture having 0.1; O.D (spectrophotometric value at $600 \mathrm{~nm}$ ) of $0.1 \mathrm{~mL}$ was spread inoculated on LB agar plate and left undisturbed for $3 \mathrm{~min}$.

\section{Preparation of agar cup wells and addition of metal solution}

Using a sterile cork borer, wells were created on LB agar plate and the chelated metal stock solution (Conc $2.0 \mathrm{mg} \mathrm{mL}^{-1}$ ) 30 micro L was added and kept for incubation at $37^{\circ} \mathrm{C}$ for $20-24 \mathrm{~h}$.

\section{Synthesis of benzyloxybenzaldehydethiosemicarbazone (BBTSC)}

Benzyloxybenzaldehydethiosemicarbazone was synthesized by refluxing a methanolic solution containing $2.0 \mathrm{~g}$ of benzyloxybenzaldehyde (M.Wt. $212 \mathrm{~g}$ ) and $1.0 \mathrm{~g}$ of thiosemicarbazide (M.Wt. $91.13 \mathrm{~g}$ ) for about $1 \mathrm{~h} 30 \mathrm{~min}$. in a round bottom flask. The light yellow colored product obtained was separated by filtration and dried. The product was recrystalized from methanol. The purity of the reagent was checked by ascertaining the melting point and elemental analysis. 


\section{Elemental analysis}

The calculated data for $\mathrm{C}_{15} \mathrm{H}_{15} \mathrm{~N}_{3} \mathrm{SO},(\mathrm{C}, 63.15 ; \mathrm{H}, 5.26 ; \mathrm{N}, 14.73 ; \mathrm{S}, 11.22 \%)$ is in good agreement with the experimentally found data $(\mathrm{C}, 61.27 ; \mathrm{H}, 5.37 ; \mathrm{N}, 14.05 ; \mathrm{S}, 9.90 \%)$ to the above proposed molecular formula for BBTSC. The synthesis of BBTSC is presented in Scheme 1.<smiles>O=Cc1ccccc1OCc1ccccc1</smiles>

Benzyloxybenzaldehyde<smiles>NNC(N)=S</smiles>

Thiosemicarbazide

Scheme 1. Synthesis of BBTSC

Benzyloxybenzaldehydethiosemicarbazone

\section{Preparation of 3,4-dihydroxybenzaldehydeisonicotinoylhydrazone $e^{43}$}

Equimolar quantities of 3,4-dihydroxybenzaldehyde (dissolved in alcohol) and isonicotinichydrazide (dissolved in water) were taken in a $500 \mathrm{~mL}$ round bottom flask and refluxed for 2-3 h. The contents were cooled and then filtered. The product (Scheme 2) obtained was washed with aqueous methanol and finally recrystallized from rectified spirit. The purity of the reagent was checked by TLC and melting point analysis (m.p. 491-492 K).

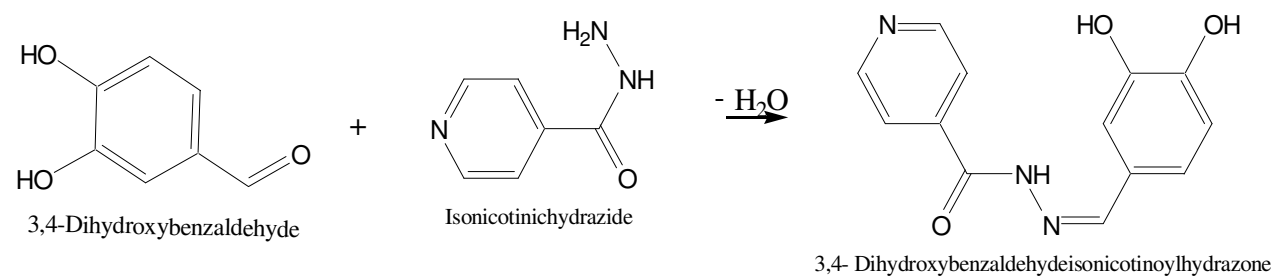

Scheme 2. Formation of 3, 4-DHBINH

\section{Results and Discussion}

\section{Characterization of BBTSC}

The synthesized reagent BBTSC was characterized by melting point determination, elemental analysis, IR (Figure 1), ${ }^{1} \mathrm{H}$ NMR (Figure 2), ${ }^{13} \mathrm{C}$ NMR (Figure 3) and Mass spectra (Figure 4).

\section{Characterization of 3,4-DHBINH}

It is evident from I.R. spectrum (Figure 5) that, $\mathrm{C}=\mathrm{N}$ group is present in the compound because the peak appears at $1600 \mathrm{~cm}^{-1} . \mathrm{C}=\mathrm{O}$ (Stretching) amide peak appears at $1656.9 \mathrm{~cm}^{-1}$. -OH group peak appears at $3484.6 \mathrm{~cm}^{-1}$, -NH peak appears at $3245 \mathrm{~cm}^{-1}$. From the above data it is confirmed the formation of 3,4-dihydroxybenzaldehydeisonicotinoylhydrazone. A $0.1 \mathrm{~mol} \mathrm{~L}^{-1}$ stock solution was prepared by dissolving $2.57 \mathrm{~g}$ of $3,4-\mathrm{DHBINH}$ in $40 \%$ aqueous dimethyl formamide(DMF).

\section{Antibacterial activity}

In the present investigation, we studied the antibacterial activity of ligands BBTSC and 3,4-DHBINH and their complexes i.e., Cu(II)-BBTSC, Pd(II)-BBTSC, V(V)-3,4-DHBINH, 
Cr(VI)-3,4-DHBINH, Ti(IV)-3,4-DHBINH and Pd(II)-3,4-DHBINH against two gram positive bacteria (Klebsiella pneumoniae and Staphylococcus aureus)and two gram negative bacteria (Escherichia coli and Pseudomonas aeruginosa). The results are reported Table 1 and Table 2.

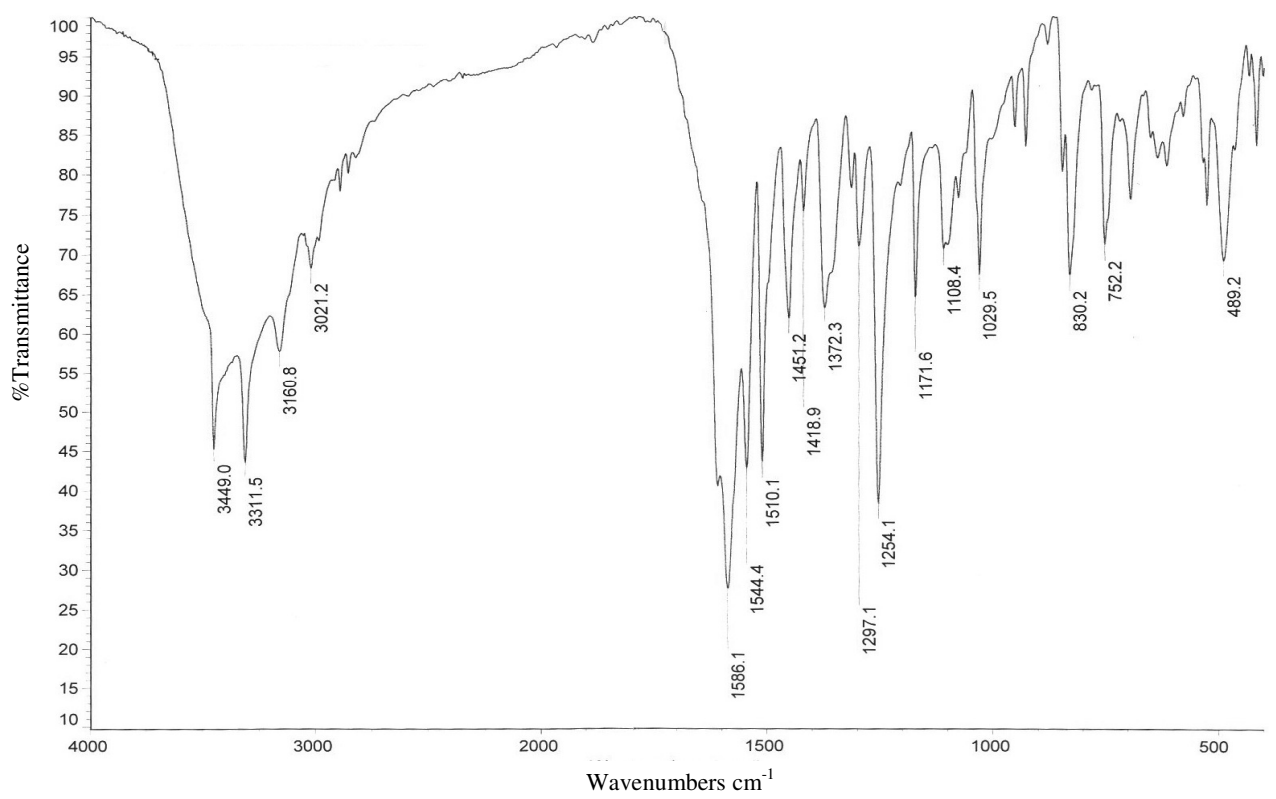

Figure 1. Infrared spectrum of BBTSC

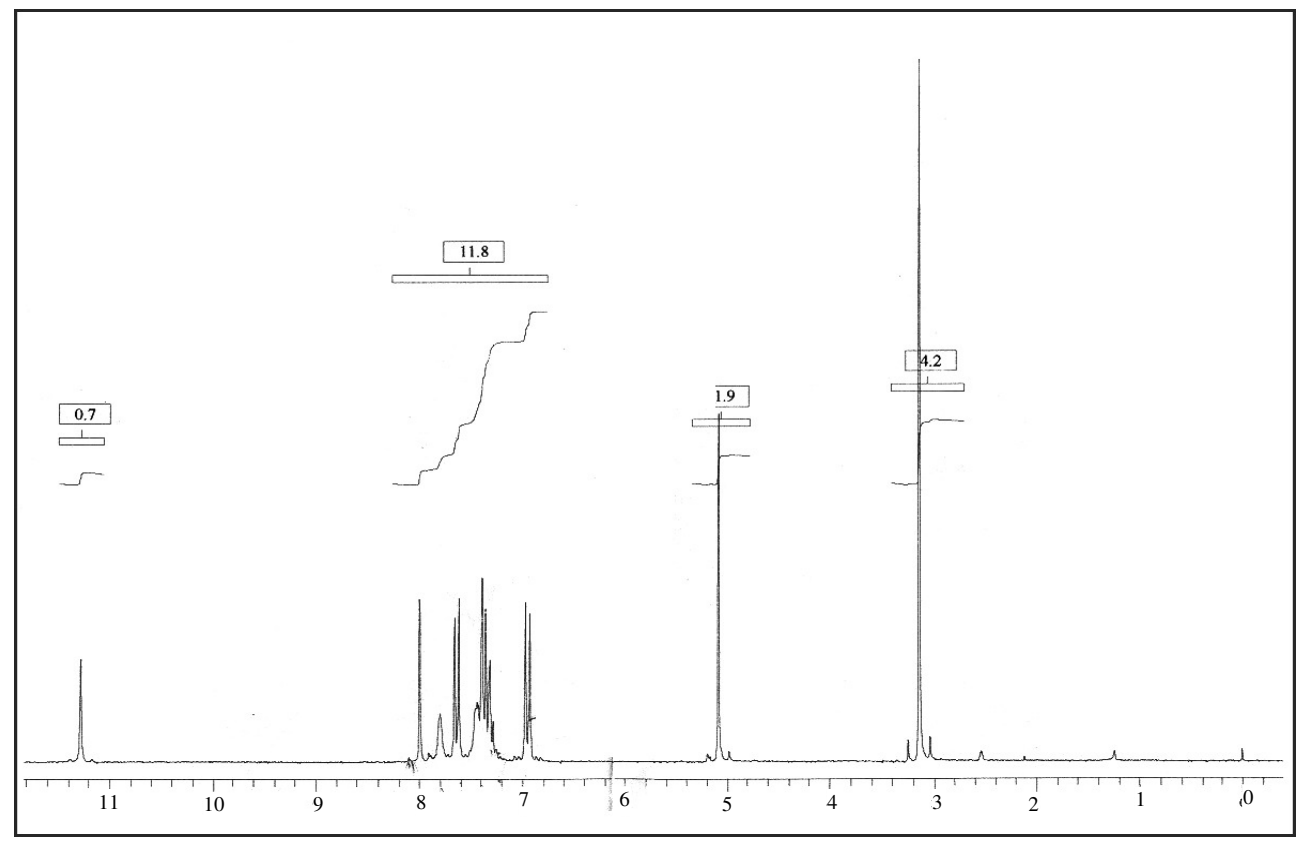

Figure 2. ${ }^{1} \mathrm{H}$ NMR spectrum of BBTSC 


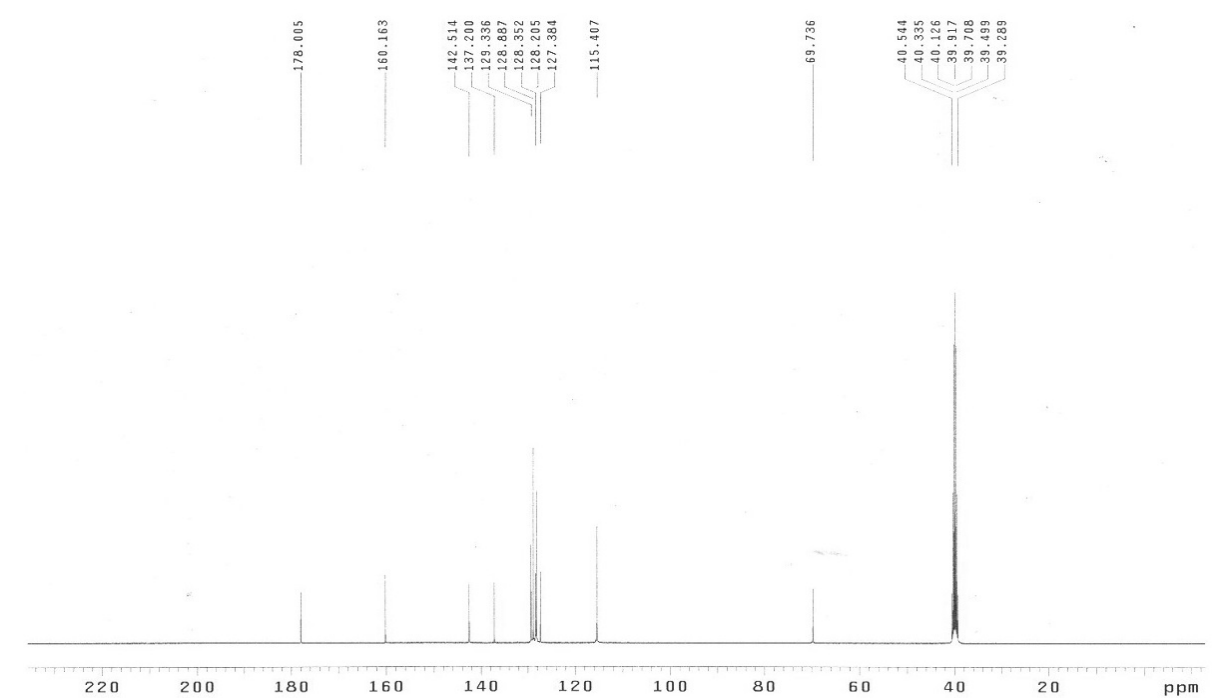

Figure 3. ${ }^{13} \mathrm{C}$ NMR spectrum of BBTSC

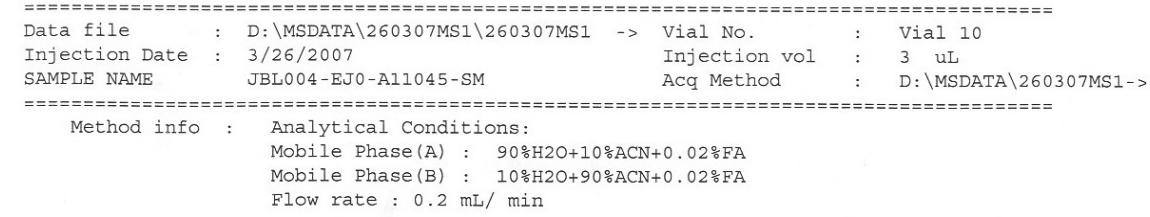

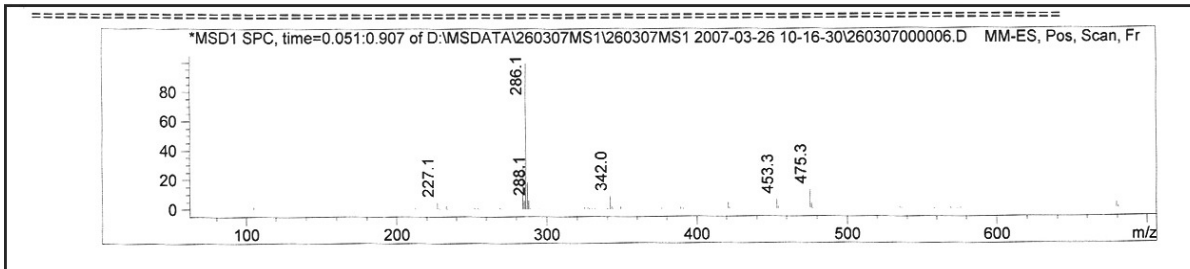

Figure 4. Mass spectrum of BBTSC

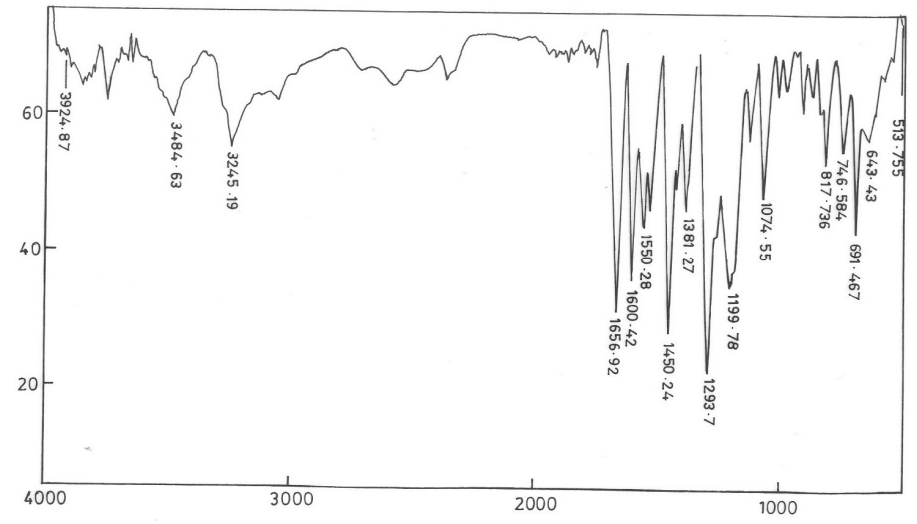

Figure 5. IR SPECTRUM of 3, 4-dihydroxybenzaldehydeisonicotinoylhydrazone 
From the data in Tables 1 and 2, it is clear that the free ligands BBTSC and 3,4-DHBINH is inactive against the tested bacteria. BBTSC, on complexation with $\mathrm{Pd}(\mathrm{II})$ and 3,4-DHBINH with Ti(IV) and Pd(II) there is a notable antibacterial activity. From the results, it is conclusive that the Pd(II) complex with 3,4-DHBINH is effective against $S$. aureus and E.coli than the Ti(IV) complex of 3,4-DHBINH. At the same time the Ti(IV) complex of 3,4-DHBINH is effective against $K$. pneumoniae and $P$. aeruginosa than the $\mathrm{Pd}(\mathrm{II})$ complex of 3,4-DHBINH. In case of $\mathrm{Pd}(\mathrm{II})$-BBTSC complex it is effective about $S$. aureus than the remaining tested bacterial stains. The minimum inhibition concentration (MIC) of these complexes found to be $1000 \mu \mathrm{g} \mathrm{mL}^{-1}$. From our observations, we conclude that the antibacterial activities are strongly dependant on the central metal ions.

Table 1. Antibacterial activity of BBTSC and its complexes

\begin{tabular}{|c|c|c|c|c|c|c|}
\hline \multirow{2}{*}{ S. No. } & \multirow{2}{*}{ Compound } & \multirow{2}{*}{$\begin{array}{c}\text { Concentration, } \\
\mu \mathrm{g} \mathrm{mL}^{-1}\end{array}$} & \multicolumn{4}{|c|}{ Minimum inhibition zone, $\mathrm{mm}^{\mathrm{a}}$} \\
\hline & & & K.pneumoniae & S.aureus & E.coli & P.aeruginosa \\
\hline \multirow{2}{*}{1} & \multirow{2}{*}{ BBTSC } & 1000 & - & - & - & - \\
\hline & & 2000 & - & - & - & - \\
\hline \multirow{2}{*}{2} & $\mathrm{Cu}(\mathrm{II})-$ & 1000 & - & - & - & - \\
\hline & BBTSC & 2000 & - & - & - & - \\
\hline \multirow{2}{*}{3} & Pd(II)- & 1000 & 7.5 & 10.0 & 5.0 & 8.0 \\
\hline & BBTSC & 2000 & 10.0 & 12.5 & 7.5 & 10.0 \\
\hline
\end{tabular}

Table 2. Antibacterial activity of 3,4-DHBINH and its complexes

\begin{tabular}{|c|c|c|c|c|c|c|}
\hline \multirow{2}{*}{ S. No. } & \multirow{2}{*}{ Compound } & \multirow{2}{*}{$\begin{array}{c}\text { Concentration, } \\
\mu \mathrm{g} \mathrm{mL}^{-1}\end{array}$} & \multicolumn{4}{|c|}{ Minimum inhibition zone, $\mathrm{mm}^{\mathrm{a}}$} \\
\hline & & & K.pneumoniae & S.aureus & E.coli & P.aeruginosa \\
\hline \multirow[t]{2}{*}{1} & 3,4-DHBINH & 1000 & - & - & - & - \\
\hline & & 2000 & - & - & - & - \\
\hline \multirow[t]{2}{*}{2} & $\mathrm{~V}(\mathrm{~V})-3,4-$ & 1000 & - & - & - & - \\
\hline & DHBINH & 2000 & - & - & - & - \\
\hline \multirow[t]{2}{*}{3} & $\mathrm{Cr}(\mathrm{VI})-3,4-$ & 1000 & - & - & - & - \\
\hline & DHBINH & 2000 & - & - & - & - \\
\hline \multirow[t]{2}{*}{4} & Ti(IV)-3,4- & 1000 & 10.0 & 8.0 & 7.0 & 10.5 \\
\hline & DHBINH & 2000 & 15.0 & 9.5 & 8.5 & 13.5 \\
\hline \multirow[t]{2}{*}{5} & Pd(II)-3,4- & 1000 & 7.5 & 9.0 & 10.0 & 7.5 \\
\hline & DHBINH & 2000 & 10.5 & 11.5 & 12.0 & 9.5 \\
\hline
\end{tabular}

${ }^{a}$ The results are average of two replicates

\section{Absorption spectra of ligands and their metal complexes}

Formation of complexes by ligands with the transition metal ions was also proved by the absorption spectra of the complexes and ligands. It is further confirmed by composition studies.

\section{Absorption spectra of BBTSC and Pd(II)-BBTSC}

The absorption spectrum of the $\mathrm{Pd}(\mathrm{II})$-BBTSC complex was recorded against reagent as blank and the absorption spectrum of BBTSC was recorded against solvent blank. The obtained 
spectra have revealed that the Pd(II)-BBTSC complex and the reagent (BBTSC) have maximum absorbances at $365 \mathrm{~nm}$ and $340 \mathrm{~nm}$, respectively. The reagent has minimum absorbance at the maximum absorbance of the complex and the reagent does not interfere with the determination of palladium(II) ${ }^{44}$.

Absorption spectra of 3,4-DHBINH, Ti(IV)- 3,4-DHBINH and Pd(II)- 3,4-DHBINH

The absorption spectrum of Ti(IV)-3, 4-DHBINH complex was recorded against the reagent blank. Similarly the absorption spectrum of the reagent (3,4-DHBINH) was recorded against the solvent blank. From the absorption spectra it is cleared that the complex and reagent have shown maximum absorptions at $370 \mathrm{~nm}$ and $340 \mathrm{~nm}$, respectively. The reagent has minimum absorbance at the maximum absorbance of the complex. The reagent absorbance at the maximum absorbance of metal complex was further suppressed using suitable concentration of reagent as blank and further absorbance measurements were made at $370 \mathrm{~nm}$. The absorption spectra in the 300-600 $\mathrm{nm}$ range for 3,4-DHBINH and $\mathrm{Pd}(\mathrm{II})-3,4-\mathrm{DHBINH}$ complex ${ }^{45}$ were recorded. The formation of the $380 \mathrm{~nm}$ band in the spectra must be connected with the chelate formation between Pd(II)- 3,4-DHBINH.

\section{Composition of the metal complexes}

\section{Composition of Pd(II)-BBTSC complex}

Job's method of continuous variation, molar-ratio method and Asmus' methods were employed to elucidate the composition of the complexes.

\section{Job's method of continuous variation}

Equimolar solutions $\left(0.5 \times 10^{-4} \mathrm{M}\right)$ of palladium(II) and BBTSC were prepared. The metal and reagent solutions were mixed in different proportions, keeping the total volume of the mixture constant at $2.0 \mathrm{~mL}$. In each case, $3.0 \mathrm{~mL}$ of sodium acetate-acetic acid buffer ( $\mathrm{pH}$ 5.0) was added to the mixture and the aqueous phase was shaken thoroughly with $10.0 \mathrm{~mL}$ of cyclohexanol. The organic phase was collected into a $25.0 \mathrm{~mL}$ standard flask and made up to the mark with cyclohexanol. The absorbances of all the organic phases were recorded at $365 \mathrm{~nm}$ against their reagent blanks. A plot was drawn between absorbance and $V_{M} / V_{L}+V_{M}$ (where $V_{L}$ and $V_{M}$ are the volumes of the reagent and the metal, respectively). From the graph, it was observed that one mole of palladium(II) reacts with one mole of ligand and the composition of metal to ligand complex as 1:1.

\section{Molar ratio method}

In molar ratio method, different aliquots containing $1.0 \mathrm{~mL}$ of $0.5 \times 10^{-4} \mathrm{M}$ palladium(II), $3.0 \mathrm{~mL}$ of sodium acetate-acetic acid buffer $(\mathrm{pH} 5.0)$ and varying concentrations $\left(0.125 \times 10^{-4}\right.$ $2.5 \times 10^{-4} \mathrm{M}$ ) of BBTSC were used to determine the metal to ligand ratio. The absorbances of the extracted organic phases were recorded at $365 \mathrm{~nm}$ against their respective reagent blanks. A plot was drawn between the absorbance and the concentration of the reagent. From the obtained curve it was confirmed that one mole of palladium(II) complexes with one mole of BBTSC. The composition of the metal to ligand was further confirmed by Asmus' method also.

\section{Composition of the Ti(IV)-3,4-DHBINH complex}

\section{Job's method of continuous variation}

Equimolar solutions $\left(1.0 \times 10^{-4} \mathrm{M}\right)$ of titanium(IV) and 3,4-DHBINH were prepared. The metal and reagent solutions were mixed in different proportions, keeping the total volume of metal and ligand constant at $1.2 \mathrm{~mL}$. In each case, $4.0 \mathrm{~mL}$ of sodium acetate-acetic acid buffer ( $\mathrm{pH} 3.5$ ) was 
added to the mixture and the total volume of the solution was made up to $10.0 \mathrm{~mL}$ with double distilled water. The absorbances of all the solutions were recorded at $370 \mathrm{~nm}$ against their reagent blanks. A plot was drawn between absorbance and $V_{M} / V_{L}+V_{M}$ (where $V_{L}$ and $\mathrm{V}_{\mathrm{M}}$ are the volumes of the reagent and the metal, respectively). From the graph, it was observed that one mole of titanaium(IV) reacts with two moles of ligand shows the composition of metal to ligand complex as 1:2.

\section{Molar ratio method}

In molar ratio method, different aliquots containing $1.0 \mathrm{~mL}$ of $1.0 \times 10^{-4} \mathrm{M}$ titanium(IV), $4.0 \mathrm{~mL}$ of sodium acetate-acetic acid buffer $(\mathrm{pH} 3.5)$ and varying concentrations $\left(0.25 \times 10^{-4}\right.$ $3.0 \times 10^{-4} \mathrm{M}$ ) of 3,4 -DHBINH were used to determine the metal to ligand ratio. The absorbances of the solutions were recorded at $370 \mathrm{~nm}$ against their respective reagent blanks. A plot was drawn between the absorbance and the concentration of the reagent. From the obtained curve it was confirmed that one mole of titanium(IV) complexes with two moles of 3,4-DHBINH.

\section{Composition of the Pd(II)-3,4-DHBINH complex}

\section{Job's method of continuous variation}

Equimolar solutions $\left(1.0 \times 10^{-4} \mathrm{M}\right)$ of palladium(II) and 3,4-DHBINH was prepared. The metal and reagent solutions were mixed in different proportions, keeping the total volume of metal and ligand constant at $1.0 \mathrm{~mL}$. In each case, $4.0 \mathrm{~mL}$ of sodium acetate-acetic acid buffer ( $\mathrm{pH}$ 3.0) was added to the mixture and the total volume of the solution was made up to $10.0 \mathrm{~mL}$ with double distilled water. The absorbance of all the solutions was recorded at $380 \mathrm{~nm}$ against their reagent blanks. A plot was drawn between absorbance and $V_{M} / V_{L}+V_{M}$ (where $\mathrm{V}_{\mathrm{L}}$ and $\mathrm{V}_{\mathrm{M}}$ are the volumes of the reagent and the metal, respectively). From the graph, it was observed that one mole of palladium(II) reacts with one mole of ligand shows the composition of metal to ligand complex as 1:1.

\section{Molar ratio method}

In molar ratio method, different aliquots containing $1.0 \mathrm{~mL}$ of $1.0 \times 10^{-4} \mathrm{M}$ palladium(II), $4.0 \mathrm{~mL}$ of sodium acetate-acetic acid buffer $(\mathrm{pH} 3.0)$ and varying concentrations $\left(0.25 \times 10^{-4}\right.$ $2.75 \times 10^{-4} \mathrm{M}$ ) of 3,4 -DHBINH were used to determine the metal to ligand ratio. The absorbances of the solutions were recorded at $380 \mathrm{~nm}$ against their respective reagent blanks. A plot was drawn between the absorbance and the concentration of the reagent. From the obtained curve it was confirmed that one mole of palladium(II) complexes with one mole of 3,4-DHBINH.

\section{Conclusion}

We confirmed the formation of BBTSC and 3,4-DHBINH with the help of various spectral techniques. The composition of the metal complexes was also evaluated by various methods. From the anti bacterial activity results, we concluded that the ligands BBTSC and 3,4-DHBINH were inactive against the tested bacteria strains. Out of six complexes the three complexes i.e., Pd(II)-BBTSC, Ti(IV)-3,4-DHBINH and Pd(II)-3,4-DHBINH are effective against the two gram positive bacteria (Klebsiella pneumoniae and Staphylococcus aureus) and two gram negative bacteria (Escherichia coli and Pseudomonas aeruginosa). The minimum inhibition zone of the complexes is increased with the increase in concentration. From our results we conclude that the antibacterial activities of the transitional metal complexes are strongly dependant of the central metal ions. 


\section{References}

1. Lobana T S, Khanna S, Butcher R J, Hunter A.D and Zeller M, Polyhedron, 2006, 25, 2755-2763.

2. Basuli F, Ruf M, Pierpont CG and Bhattacharya S, Inorg Chem., 1998, 37, 6113-6116.

3. Dessy G, Fares V, Scaramuzza L, Tomlinson A A G and De Munno G, J Chem Soc., Dalton Trans., 1978, 1549-1554,.

4. Kovala-Demertzi D, Yadav P N, Wiecek J, Skoulika S, Varadinova T and Demertzis M A, J Inorg Biochem., 2006, 100(9), 1558-1567.

5. Logan J C, Fox M P, Morgan J H, Makohon A M and Pfau C J, J Gen Virol., 1975, 28, 271.

6. Blanz E J and French F A Jr, Cancer Res., 1968, 28(12), 2419-2422.

7. Klayman D L, Bartosevich F J, Griffin T S, Mason C J and Scovill J P, J Med Chem., 1979, 22, 855.

8. $\quad$ Mittal S P, Sharma S K, Singh RV and Tandon J P, Curr Sci., 1981, 50, 483.

9. Dobeck A S, Klayman D L, Dickson E J, Scovill J P and Tramont E C, Antimicrob Agents Chemother., 1980, 18, 27.

10. Gomez Quiroga A and Navarro Raninger C, Coord Chem Rev., 2004, 248, 119-133.

11. Farrell N, Coord Chem Rev., 2002, 232, 1-4.

12. Abram U, Ortner K, Gust R and Sommer K, J Chem Soc Dalton Trans., 2000, 735.

13. Belicchi-Ferrari M, Bisceglie F, Casoli C, Durot S, Morgenstern-Badara I, Pelosi G, Pilotti E, Pinelli S and Tarasconi P, J Med Chem., 2005, 48, 1671-1675.

14. Arion V B, Jakupec M A, Galanski M, Unfried P and Keppler B K, J Inorg Biochem., 2002, 91, 298.

15. Patole J, Padhye S, Moodbidri M S and Shirsat N, Eur J Med Chem., 2005, 40, 1052-1055.

16. Agrawal K C and Sartorelli A C, Prog Med Chem., 1978, 15, 321-356.

17. Nomiya K, Tsuda K and Kasuga N C, J Chem Soc Dalton Trans., 1998, 1653.

18. Quiroga A G, Perez J M, Lopez-Solera I, Massaquer J R, Luque A, Roman P, Edward A, Alonso C and Navarro-Ranninger C, J Med Chem., 1998, 41, 1399.

19. Matesanz A I, Perez J M, Navarro P, Moreno J M, Colacio E and Souza P, J Inorg Biochem., 1999, 76, 29-37.

20. Perez J M, Quiroga A G, Montero E I, Alonso C and Navarro-Ranninger C, J Inorg Biochem., 1999, 73, 235.

21. Collins F M, Klayman D L and Morrison N E, J Gen Microbiol., 1982, 128, 1349.

22. Williams DR, Chem. Rev., 1972, 72, 203.

23. John R P, Sreekanth A, Rajakannan V, Ajith T A and Kurup M R P, Polyhedron, 2004, 23, 2549-2559.

24. Belicchi-Ferrari M, Bisceglie F, Casoli C, Durot S, Morgenstern-Badarau I, Pelosi G, Pilotti E, Pinelli S and Tarasconi P, J Med Chem., 2005, 48, 1671.

25. Kovala-Demertzi D, Boccarelli A, Demertzis M A and Coluccia M, Chemother., 2007, 53, 148-152.

26. Elena B, Rosa C, Alfonso C, Ricardo-Dominguez, Anthony E L, Cacillia Maichle-Mossmer, Michelle M S and Douglas X West, Eur J Inorg Chem., 1999, 965.

27. Dimitra Kovala-Demertzi, Maroudis A. Demertzis, Miller J R, Cryshanthi Papadopoulou, Catherine Dodorou and Giorge Filousis, J Inorg biochem., 2001, 86, 555.

28. Sulekh Chandra, Smriti Raizada, Monika Tyagi and Archana Gautam, Bioinorg Chem Appl., 2007, 1, 51483.

29. Jayabalakrishanan C and Natarajan K, Synt React Inorg Met Org Chem., 2001, 31, 983-995. 
30. Jeeworth T, Wah H L K, Bhowon M G, Ghoor hoo D and Babooram K, Synth React Inorg Met Org Chem., 2000, 30, 1023.

31. Dharmaraj N, Viswanathamurthi P and Natarajan K, Trans Met Chem., 2001, 26, 105-109.

32. Savini L, Chiasserini L, Gaeta A and Pellerano C, Bioorg Med Chem., 2002, 10, 2193-2198.

33. Ferrari M B, Capacchi S, Pelosi G, Reffo, Tarasconi P, Alberlini R, Pinelli S and Lunghi P, Inorg Chim Acta, 1999, 286, 134-141.

34. Agarwal R K, Singh L, Sharma D K and Singh R, Turk J Chem., 2005, 29, 309.

35. Elo H, Sunila I and Lumme P, Inorg Chim Acta, 1987, 136(1), 149.

36. Ragavendran J, Sriram D, Patel S, Reddy I, Bharathwajan N, Stables J and Yogeeswari P, Eur J Med Chem., 2007, 42, 146-151.

37. Abdel-Aal M T, El-sayed W A and El-Ashry E H, Arch Pharm Chem Life Sci., 2006, 339, 656-663.

38. Walcourt A, Loyevsky M, Lovejoy D B, Gofdeuk V R and Richardson D R, Int J Biochem Cell Biol., 2004, 36(3), 401-417.

39. Savini L, Chiasserini L, Travagli V, Pellerano C, Novellino E, Cosentino S and Pisano M B, Eur J Med Chem., 2004, 39(2), 113-122.

40. Nayyar A and Jain R, Curr Med Chem., 2005, 12, 1873-1886.

41. Scior T and Garces-Eisele S J, Curr Med Chem., 2006, 13, 2205-2219.

42. Janin Y, Bioorg Med Chem., 2007, 15, 2479-2513.

43. Sah P P T and Peoples S A, J Am Pharm Assoc., 1954, 43, 513-524.

44. Lakshmi Narayana S, Janardhan Reddy K, Adinarayana Reddy S, Kumar J R and Reddy AV, J Chin Chem Soc., 2007, 54, 1233-1241.

45. Lakshmi Narayana S, Ramachandraiah C, Varada Reddy A, Dong-Yan Lee and Jaesool Shim, E-J Chem., 2011, 8(1), 217-225. 


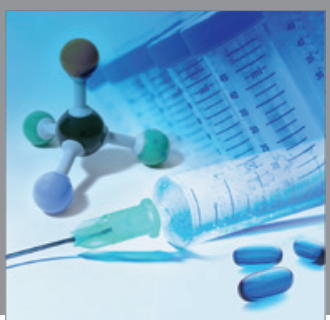

International Journal of

Medicinal Chemistry

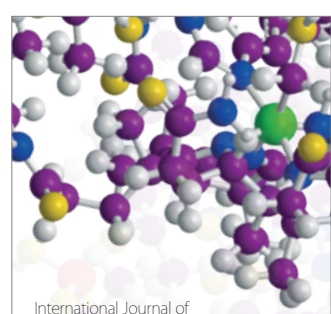

Carbohydrate Chemistry

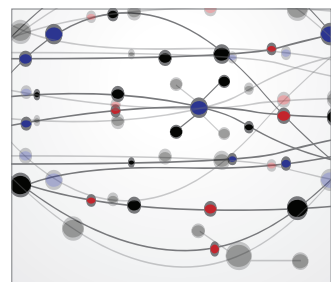

The Scientific World Journal
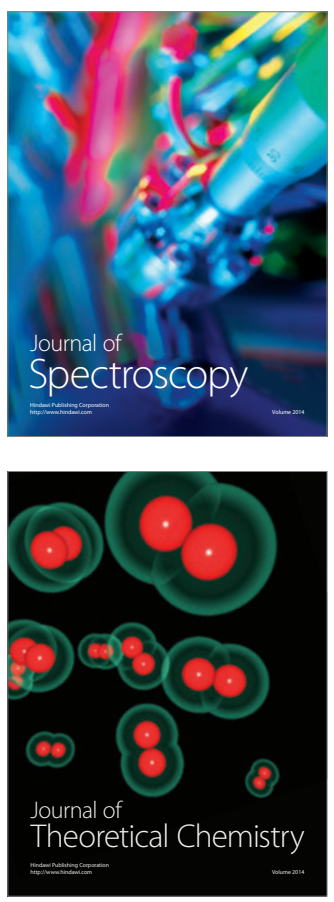
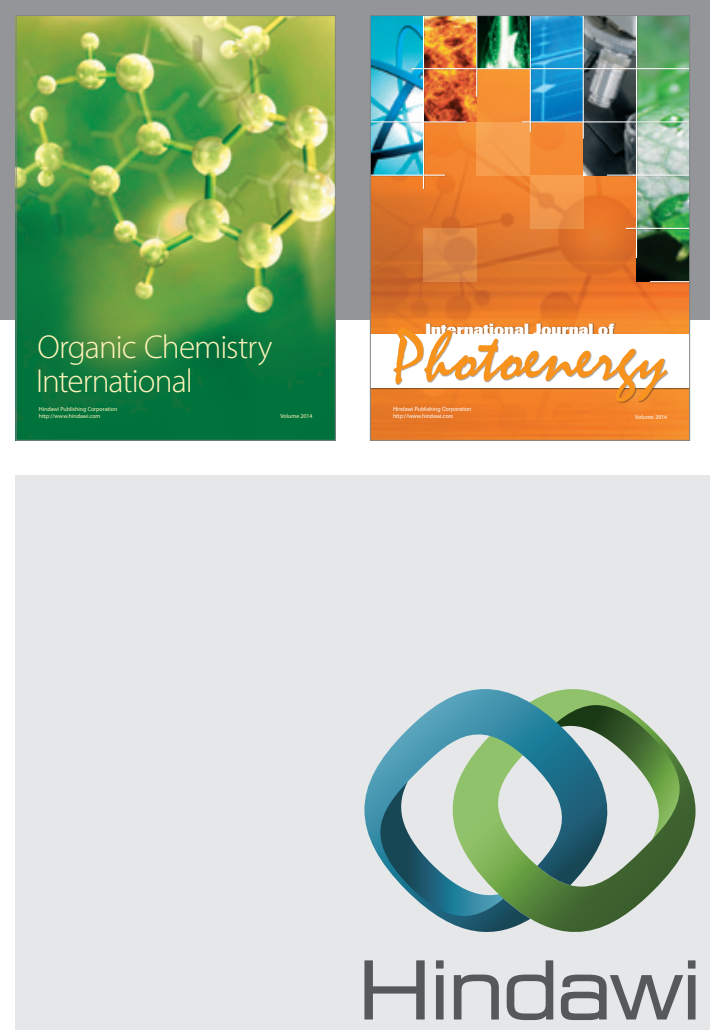

Submit your manuscripts at

http://www.hindawi.com
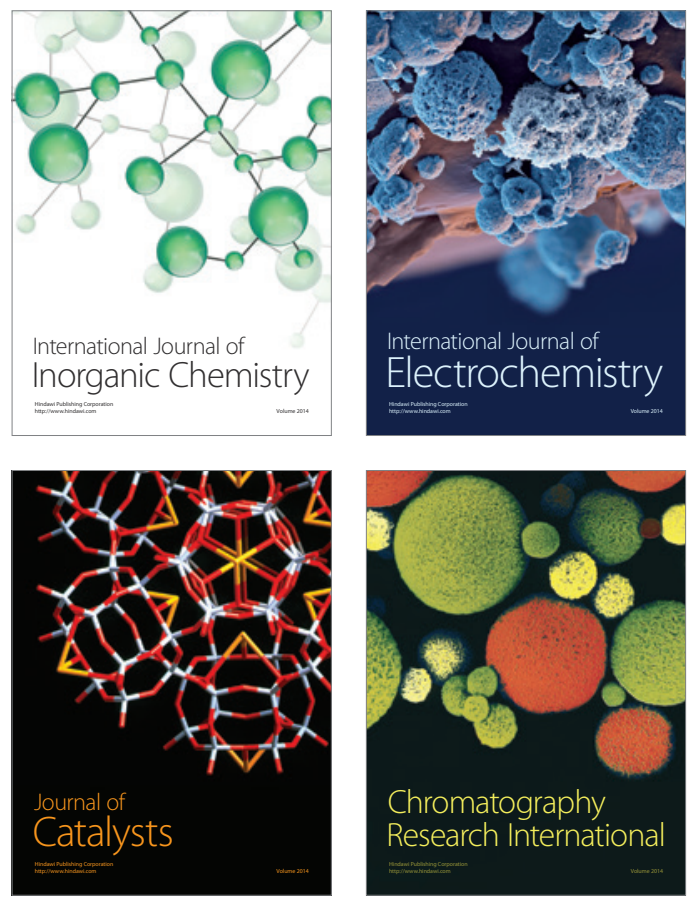
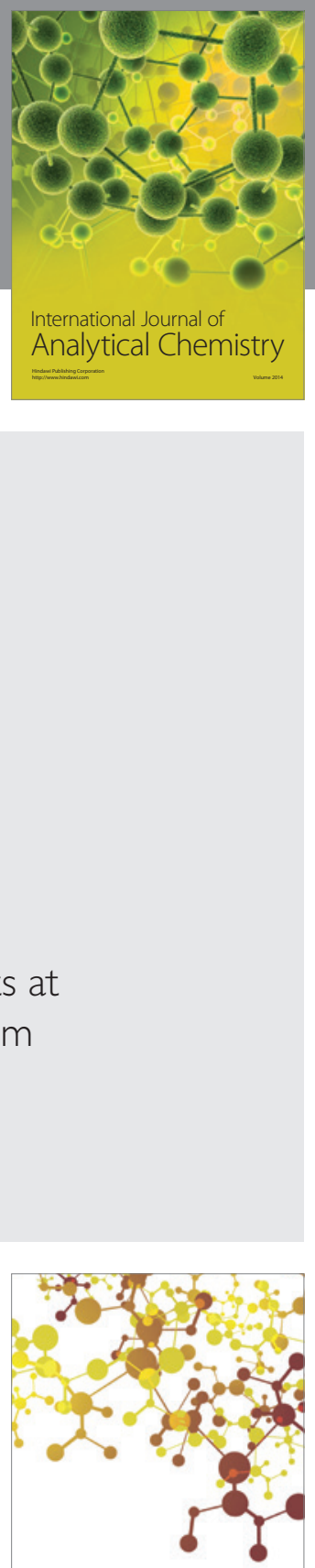

Journal of

Applied Chemistry
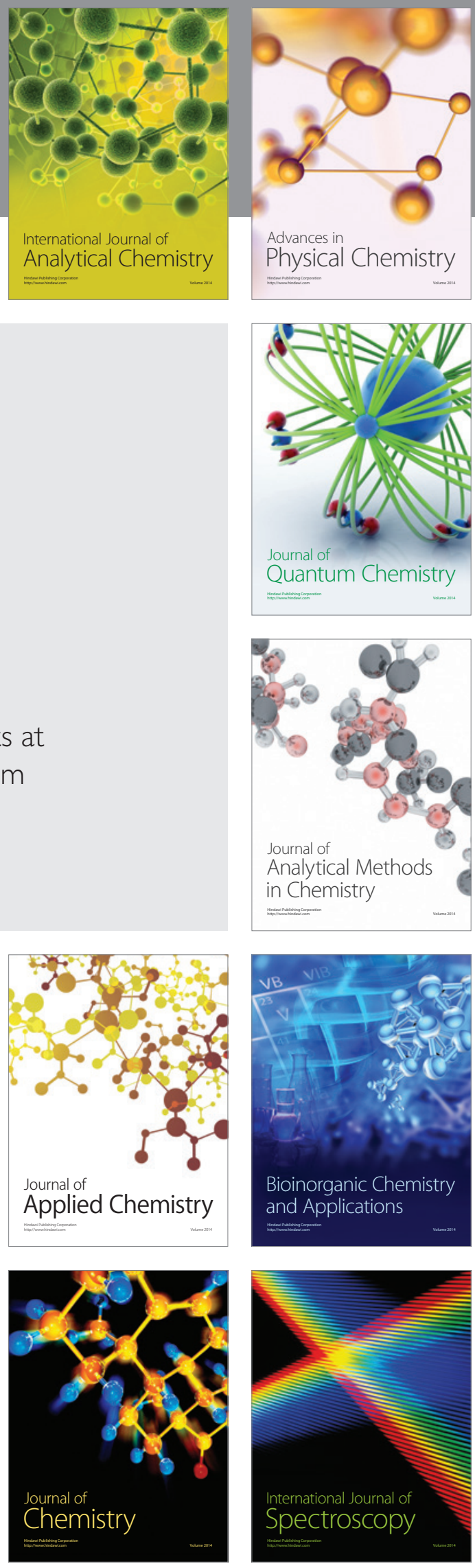